\title{
MORPHOLOGICAL CHANGES ACCOMPANYING THE TRANSITION FROM JUVENILE (ATMOSPHERIC) TO ADULT (TANK) FORMS IN THE MEXICAN EPIPHYTE TILLANDSIA DEPPEANA (BROMELIACEAE) ${ }^{1}$
}

\author{
William W. Adams III ${ }^{2}$ and Craig E. Martin \\ Department of Botany, University of Kansas, Lawrence, Kansas 66045
}

\begin{abstract}
A B S T R A C T
Two distinct morphological forms characterize the ontogenetic development of the epiphytic bromeliad Tillandsia deppeana. Juveniles are characterized by a non-impounding rosette of small, linear leaves covered with elaborate trichomes possessing a $4+8+16+64$ shield cell pattern. The broader transitional leaves, which form an impounding rosette prior to the initiation of true adult leaves, also possess trichomes with the $4+8+16+64$ cell pattern. Adult individuals have large, broad leaves with overlapping, sheathing bases which impound water and debris. These leaves have trichomes with shields exhibiting a $4+8+32$ cell pattern. Trichome density is fairly uniform in the juvenile leaves with trichomes covering $100 \%$ of leaf surfaces, whereas in the adult leaves density is high at the base and diminishes significantly toward the apex. Stomatal density of both juvenile and adult leaves increases from the base to the apex, although this is most pronounced in the adults. Stomata in the adults are also arranged in longitudinal series parallel and abaxial to parallel rows of mesophyll tissue. The results of this study indicate that juveniles of $T$. deppeana are more similar morphologically to adult atmospheric-type tillandsioid species than to the tank-forming adults into which they eventually develop.
\end{abstract}

THE EXTREMES IN adaptive form present in epiphytic members of the Bromeliaceae are represented by atmospheric and tank-forming species of the subfamily Tillandsioideae. Although these two forms represent different approaches to the acquisition and retention of water and nutrients, both are dependent on a feature common within the subfamily-the stalked, peltate trichomes that are highly specialized for the absorption of water and nutrients.

Atmospheric tillandsioids are often characterized by succulent leaves having a relatively large volume of hypodermis tissue (Tomlinson, 1969; Benzing and Burt, 1970) and a dense indumentum of elaborate trichomes which obscure the leaf surface. When dry, shoots of these species appear silvery-gray

\footnotetext{
' Received for publication 21 September 1984; revision accepted 20 February 1986.

The authors wish to thank W. Adams, Jr., E. Adams, and J. Adams for help in the collection of the plant specimens, F. D). Tibbitts for assistance in the preparation of tissues for sectioning and photographing, D. Benzing, J. Matos, and ( $\mathrm{R}$. Rudolph for stimulating discussions, $\mathrm{K}$. Koster for assistance in the translation of several foreign language articles, $S$. Smith for improvements to the manuscript, and J. Elder, ( $'$. Haufler, T. Ranker, and C. Spencer for assistance in the preparation of the manuscript.

${ }^{2}$ Present address and address for reprint requests: Department of Environmental Biology, Research School of Biological Sciences. The Australian National University, P.O. Box 475, Canberra, ACT 2601, Australia.
}

by virtue of light reflection from the large shields of the trichomes. When wetted, these shields facilitate the movement of water over the leaf surface by capillary action, enhancing the uptake of water and dissolved minerals (Tomlinson, 1969; Benzing and Burt, 1970; Benzing, 1976; Benzing et al., 1976).

The tank-forming tillandsioids are characterized by wide, flat, trough-shaped leaves with expanded bases that overlap to form watertight chambers within which water and debris are impounded (Benzing, 1973, 1980). In order to intercept and retain water and debris, the shoots of these plants are negatively geotropic, unlike the atmospheric forms which are typically ageotropic. The leaves of tank formers do not have the silvery-gray appearance of the atmospherics since the trichome shields of the former are more reduced (or lacking) and the density of trichomes over the foliar surface is lower than in the atmospheric tillandsioids. As a result, the leaf surfaces of the tank formers are hydrophobic, funneling water into the impounding leaf bases (Benzing, 1973). Water and minerals can subsequently be absorbed through the trichomes found on the sheathing leaf bases. The tank-forming tillandsioids are thus able to maintain a reservoir of water and nutrients for use during periods between precipitation events.

The division of the epiphytic tillandsioids into two major morphological types, atmo- 
spheric and tank-forming, is not always clearcut, as there are species which tend to grade between the two forms (Pittendrigh, 1948; Tomlinson, 1970; Benzing and Burt, 1970; Benzing, 1980). In addition, juveniles of at least some of the epiphytic, tank-forming tillandsioids exhibit morphological characteristics of the atmospheric forms (Morren, 1873; Mez, 1904; Lieske, 1914; Tomlinson, 1969, 1970; Benzing and Burt, 1970; Benzing, 1980). Whether all epiphytic tank-forming tillandsioids initially pass through a juvenile phase such as this is not known.

The seedlings of epiphytic tillandsioids have received very little attention, and yet it is this stage which is most important in the establishment of an epiphyte in a particular habitat (Tomlinson, 1969). Lieske (1914) examined the change in leaf form from the atmospheric seedling to the tank-forming adult in three genera of the Tillandsioideae and included observations on differences in trichome density that accompany this change. Since Lieske's work, however, there has been no further examination of this ontogenetic change in life form. This dearth of information has persisted despite the fact that numerous authors have referred to such transitions and speculated on their role in putative evolutionary trends within the subfamily Tillandsioideae, if not the entire family (Lieske, 1914; Schulz, 1930; Tomlinson, 1969, 1970; Benzing and Burt, 1970; McWilliams, 1974; Medina, 1974; Benzing, 1976, 1980).

Tillandsia deppeana is a tank-forming epiphyte found in pine and deciduous forests in Mexico, the West Indies, Central America, and northern and western South America (Padilla, 1973; Smith and Downs, 1977; Rauh, 1979). This species has been reported to pass through an atmospheric stage as a seedling and juvenile (Benzing, 1980; Matos and Rudolph, 1984; Adams and Martin, 1986a). It is the purpose of this study to assess the extent to which juvenile and adult forms of this epiphyte possess morphological characteristics of adult atmospheric and tank-forming tillandsias.

MATERIALS AND METHODS-Plants were collected from a site in the Eastern Sierra Madre Mountains in the state of San Luis Potosí, Mexico, in an oak woodland with a thorn shrub understory. The majority of the oak limbs extend laterally from the trunk and are covered with vascular and non-vascular epiphytes: lichens, mosses, Selaginella sp., several species of ferns, a stonecrop, orchids, and several species of Tillandsia including $T$. bartramii, $T$. deppeana, T. usneoides, and T. parryi.

Three collections were made: in December
1982 (when it was misty and cool), March 1983 (hot, dry, and windy), and December 1983 (cloudy and cold). Water was always present in the adult tanks of $T$. deppeana, and was frozen at mid-morning in December of 1983 (these individuals appeared undamaged and grew vigorously when returned to Kansas).

The plants were removed from the trees and returned to the University of Kansas where they were maintained on screen (juveniles) and wood or sand (adults) in a greenhouse. Environmental conditions in the greenhouse were: maximum photosynthetically active radiation of $1,000 \mu \mathrm{mol} \cdot \mathrm{m}^{-2} \cdot \mathrm{s}^{-1} ; 15-16 \mathrm{hr}$ photoperiod; maximum day/night air temperatures of $35 / 20 \mathrm{C}$; maximum day/night relative humidities of $40 / 80 \%$. Plants were watered every two or three days and received nutrients (Hoagland and Arnon, 1938) two to three times monthly.

The development of $T$. deppeana was documented with photographs of individuals at various stages of development. Foliar surface features were examined with a Phillips 501 scanning electron microscope or a Perkin/Elmer ETEC-Autoscan. Where necessary, leaf specimens were dehydrated in an acetone series, critical point dried, and coated with goldpalladium. Some tissue, however, gave better results when examined fresh and untreated. The tissues used in sectioning were fixed in AFA (ethanol, formalin, and acetic acid), taken through an ethanol, xylene, and paraffin series, embedded in paraffin, sectioned at $15 \mu \mathrm{m}$ (juvenile) or $20 \mu \mathrm{m}$ (adult), and mounted on glass slides. After removal of the paraffin, the sections were stained for $24 \mathrm{hr}$ in a mixture of Orange II ( 2 parts) and Biebrich Scarlet (1 part) after which they were stained for $1 \mathrm{~min}$ in Crystal Violet. Where appropriate, data were analyzed using a $t$-test for the comparison of two means (Sokal and Rohlf, 1981).

RESULTS-Atmospheric juveniles of $T$. deppeana are found throughout the canopy and on understory shrubs, often growing together in clumps (Fig. 1). Juvenile-to-adult transitional forms and smaller adults without atmospheric juvenile leaves also occur in all portions of the canopy. The larger adults are found primarily in the upper canopy on the upper sides of large limbs (Fig. 2). All of the adults exhibit strong negative geotropism, resulting in the impoundment of water and debris in their sheathing leaf bases.

Tillandsia deppeana juveniles exhibit morphological features commonly found among adults of atmospheric tillandsioid species while the adults possess a characteristic tank habit and morphology. The juveniles have small, linear leaves $(5-6 \mathrm{~cm}$ in length before the tran- 


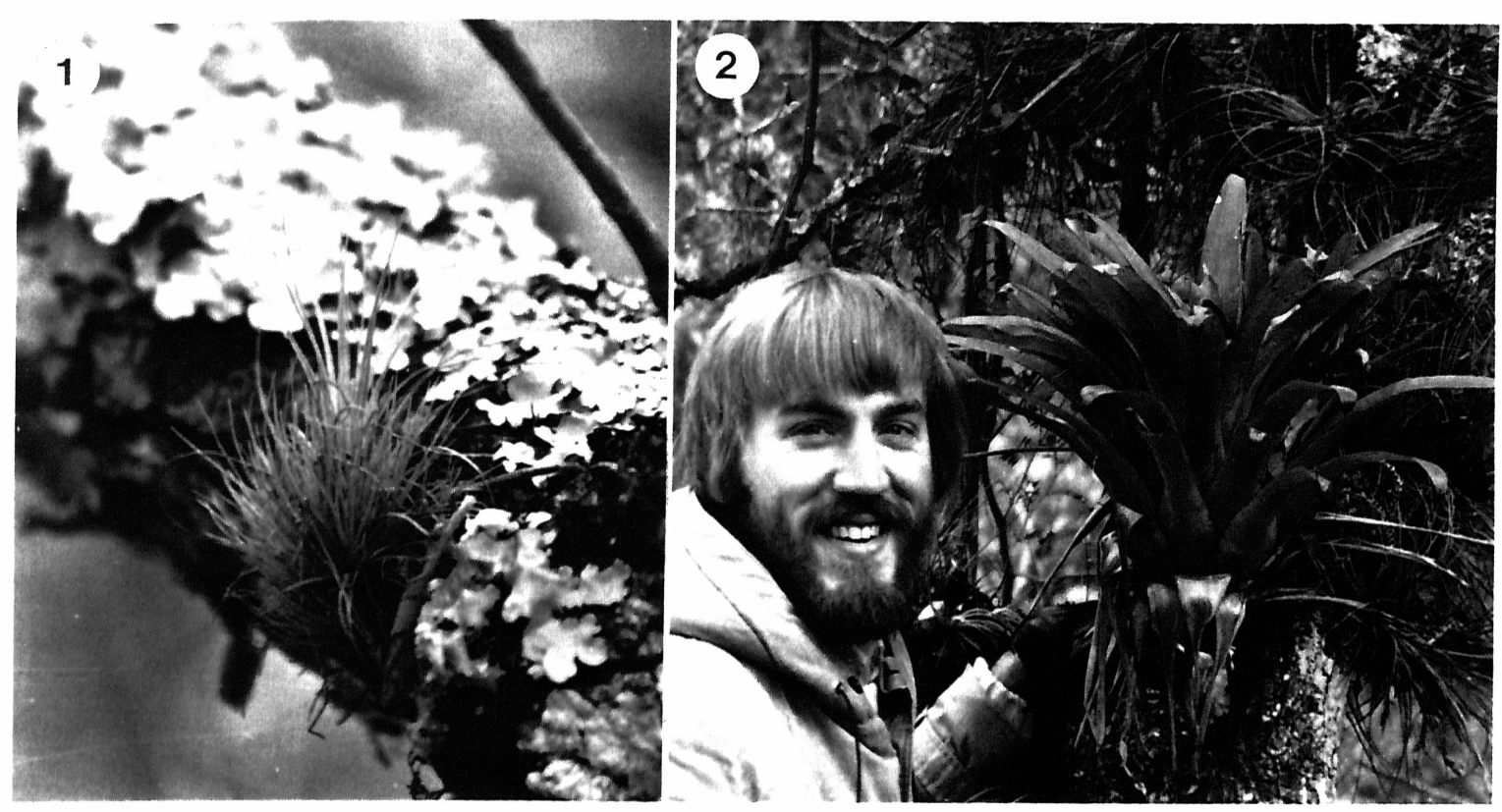

Fig. 1-2. Individuals of Tillandsia deppeana at the study site in San Luis Potosí, Mexico in late December 1983. 1. Juvenile form (approximately $5 \mathrm{~cm}$ high). 2. Adult form with $T$. bartramii in background.

sition is initiated) arranged in non-impounding rosettes (Fig. 1, 3,7). There can be 70 or more leaves in the juvenile rosette before transition leaves begin to develop. The juvenile trichomes have large, overlapping shields which cover $100 \%$ of the leaf surface (Fig. 11). The trichome shield consists of four central cells surrounded by two concentric sets of ring cells (eight cells in the first ring and 16 in the second) which are in turn surrounded by a ring of 64 elongated wing cells, although this latter number is variable (as many as 75 cells have been observed in the wings of some shields).

The transition from atmospheric juvenile to young tank-forming adult is illustrated in Fig. 3-10. New leaves in the center of the rosette broaden to initiate the development of an impounding rosette. The transition is gradual, with the first transitional leaves broadening only slightly and successive leaves broadening to a greater extent. Transitional leaves are similar to adult leaves in overall form (broad and flat) but are still covered with trichomes having the $4+8+16+64$ cell pattern characteristic of juvenile leaves (Fig. 12). These trichomes, however, do not cover $100 \%$ of the leaf surface as they do in the juvenile plants. A complete impounding rosette of these transitional leaves forms before true adult leaves begin to develop. Juvenile leaves are also maintained for some time after the transition has been initiated (Fig. 3-10).

The adult leaves may attain lengths of 0.5 $\mathrm{m}$ and are broad and flat with sheathing bases (Fig. 2). Each of the overlapping leaf bases forms a separate, watertight tank within which water and debris are held. The trichome shield on the adult leaf (Fig. 13-14) is dissimilar to that found in the juvenile and transitional leaves. Instead of two sets of concentric ring cells surrounding the four central cells there is but a single ring of eight cells. This is in turn surrounded by a reduced ring of wing cells which consists of a variable number of cells from 20 to 32 . The number of wing cells toward the distal portion of the leaf more commonly approaches 32 .

Trichome density is uniform throughout the juvenile leaf while in the adult leaf it is higher in the basal portion and decreases progressively toward the apex (Table 1). There is also a significantly greater number of trichomes on the adaxial surface than on the abaxial surface of the adult leaf bases. The trichomes totally obscure the stomata in the juvenile leaves whereas the stomata are never covered by trichomes in the adult leaves (compare Fig. 11, 14). The stomata are abaxial and at a higher density on the distal portion of both the juvenile and adult leaves (Table 1). This difference is accentuated in the adults, in which stomata are nearly absent from the sheathing leaf bases where no chlorophyllous mesophyll tissue is present (Fig. 13). Only veins and uniform, colorless parenchyma cells are present in the leaf base, although purple anthocyanins may develop in cells of older leaves.

The stomata in the adult leaf are oriented with the long axis of the guard cells parallel to the long axis of the leaf (Fig. 14). They are 


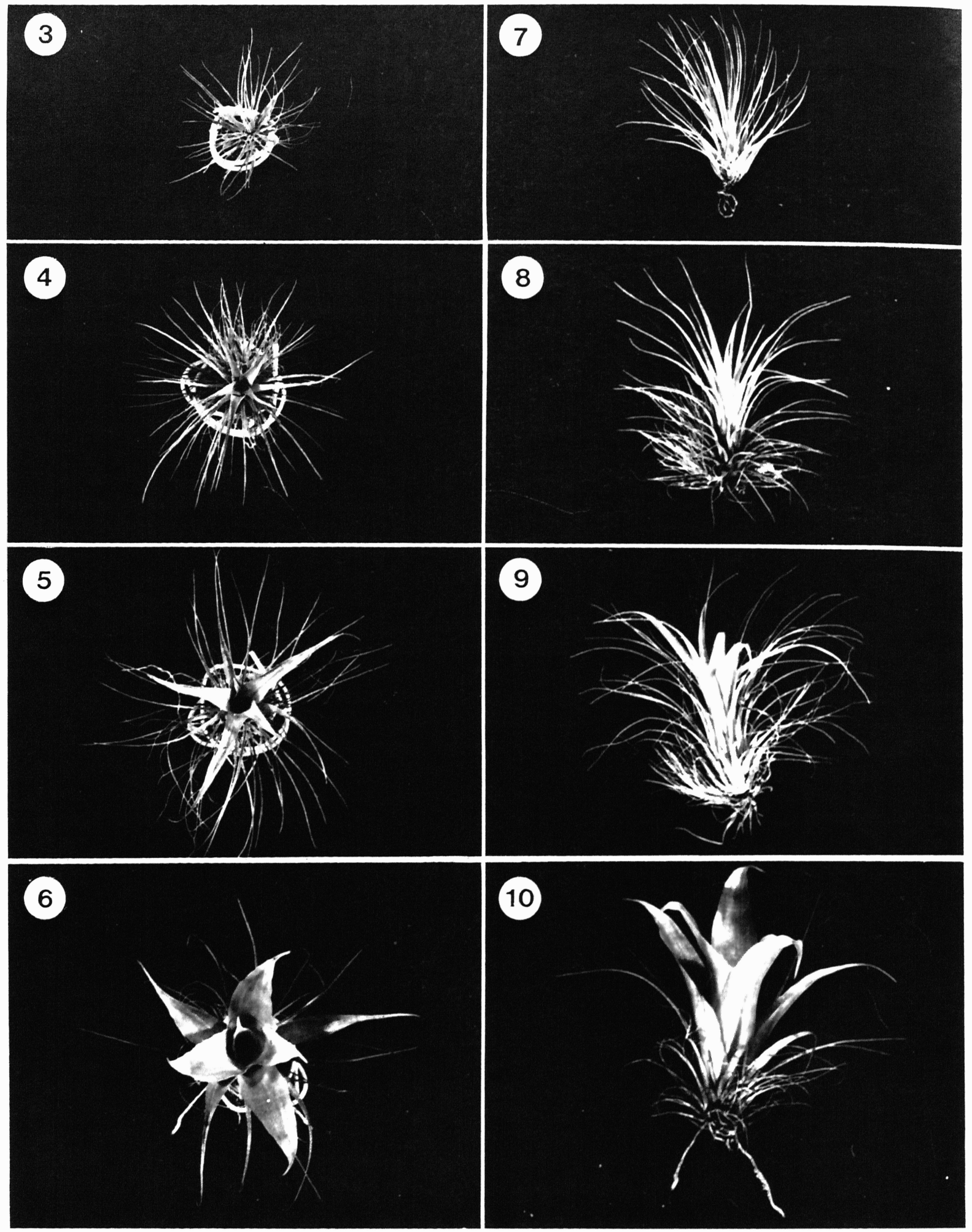

Fig. 3-10. Early stages in the transition of Tillandsia deppeana from an atmospheric juvenile to a tank-forming adult. 3-6. View from above. 7-10. Side view. Plant height is approximately 5, 7, 8, and $9 \mathrm{~cm}$, respectively.

arranged in series that are parallel with the long axis of the leaf and are located directly below rows of chlorophyllous mesophyll tissue (Fig. 14, 16). Vascular strands run the length of the leaves between the chlorenchyma. These veins are located about midway between the adaxial and abaxial surfaces and are surrounded by ensheathing fiber cells (Fig. 16). The vascular 

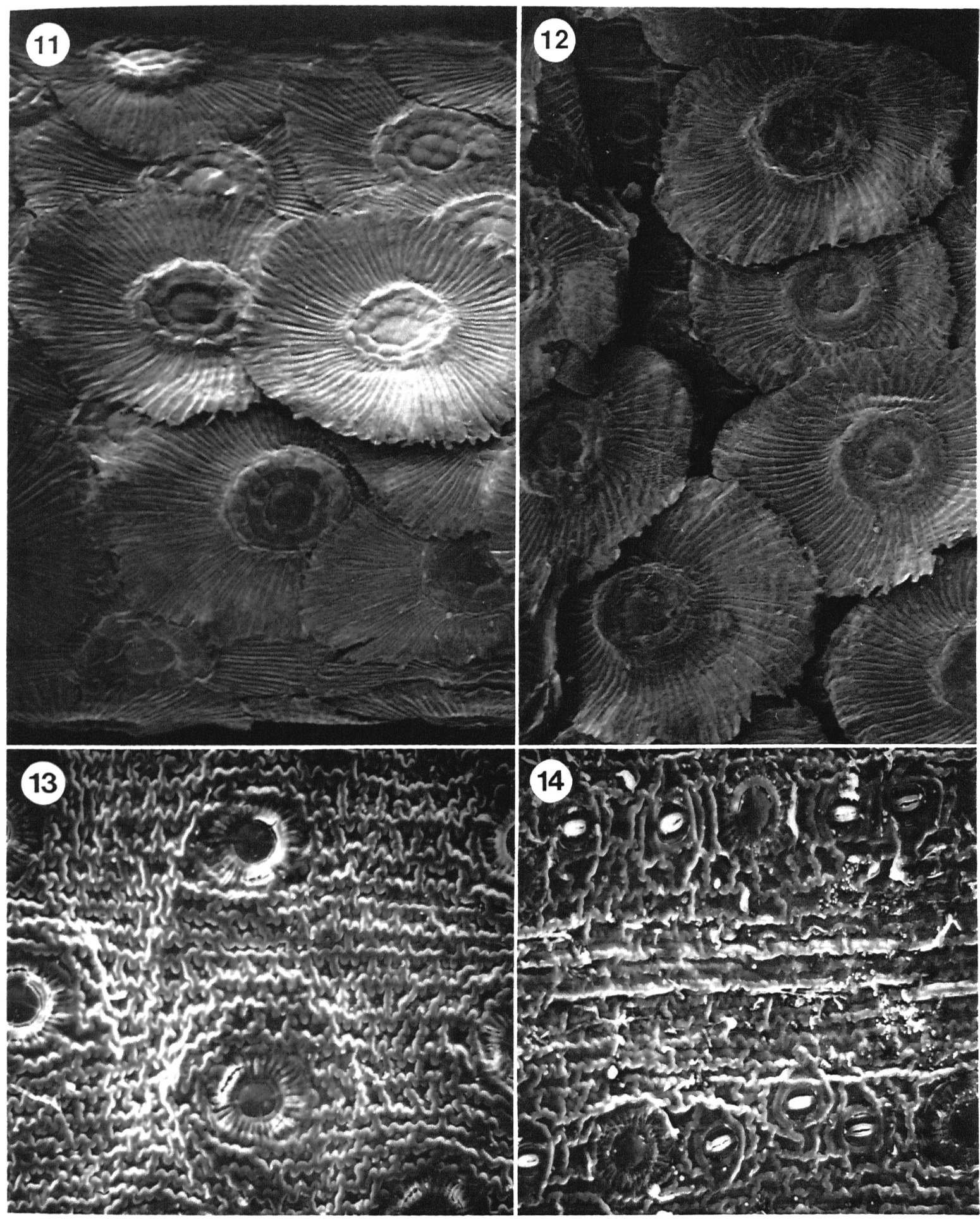

Fig. 11-14. Scanning electron micrographs of Tillandsia deppeana leaf surfaces. 11. Abaxial surface of juvenile leaf. $\times 160.12$. Abaxial surface of transitional leaf. $\times 160$. Note stomatal complex revealed by uplifted trichome shield. 13. Abaxial surface of sheathing, basal portion of adult leaf. $\times 160$. 14. Abaxial surface of distal portion of adult leaf. $\times 160$.

bundles differ in size, larger ones alternating with smaller ones from one side of the leaf to the other. A distinct adaxial hypodermis composed of large, colorless cells is present above the veins and chlorenchyma. There is also an abaxial hypodermis which is more irregular and less distinct in depth. The epidermis is a single cell layer and the cuticle is too thin to be discerned at these magnifications.

The juvenile leaves are round to oblong in 
TABLE 1. Mean densities of trichomes and stomata in different portions of juvenile and adult leaves of Tillandsia deppeana. Standard deviations are given in parentheses. Each pair of means is not significantly different (ns) or significantly different at $P<0.05^{*}$ ) or $\left.P<0.0011^{* * *}\right)$

\begin{tabular}{ccc}
\hline \hline $\begin{array}{c}\text { Life form, leaf portion, } \\
\text { and surface }\end{array}$ & $\begin{array}{c}\text { Trichome density } \\
\text { trichomes } \mathrm{mm}^{-2}\end{array}$ & $\begin{array}{c}\text { Stomatal density } \\
\text { stomata } \mathrm{mm}^{-2}\end{array}$ \\
\hline $\begin{array}{l}\text { Juvenile }(N=25) \\
\text { Abaxial surface }\end{array}$ & & \\
$\quad$ Basal portion & $27.4(5.5)$ & $16.6(6.7)$ \\
$\quad$ Distal portion & $29.8(4.4)^{\mathrm{ns}}$ & $24.1(6.0)^{* * *}$ \\
Adult $(N=50)$ & & \\
Basal portion & & \\
Adaxial surface & $63.4(12.5)$ & 0.0 \\
Abaxial surface & $46.2(9.1)^{* * *}$ & $0.1(0.4)$ \\
Mid portion & & \\
Adaxial surface & $17.6(6.0)$ & 0.0 \\
Abaxial surface & $15.1(5.3)^{*}$ & $8.8(3.5)$ \\
Distal portion & & \\
Adaxial surface & $8.8(2.5)$ & 0.0 \\
Abaxial surface & $9.4(2.0)^{\mathrm{ns}}$ & $40.7(11.3)$ \\
\hline
\end{tabular}

transverse section with a slight invagination in the center of the adaxial surface (Fig. 15). These leaves have a greater proportion of adaxial hypodermis relative to chlorenchyma than do the adult leaves.

Reproduction in $T$. deppeana can occur either sexually or vegetatively. An inflorescence is initiated in the center of an adult rosette and may grow as high as $0.5 \mathrm{~m}$. After the seeds have matured the adult rosette dies. Vegetative reproduction occurs when offshoots develop from the stem of the mother plant. These offshoots are initiated during sexual reproduction or when the meristematic region of an adult plant is damaged. The offshoots develop between the overlapping leaf bases and exhibit adult leaves only. Their rate of growth, however, is much more rapid than that of an adult developing from a juvenile.

DisCUSSION-The presence of heterophylly in the tank-forming Tillandsia heterophylla was noted briefly by Morren (1873) and Mez (1904), but the only study to document the phenomenon was that by Lieske (1914). He indicated that atmospheric juveniles are present in tankforming species of the tillandsioid genera Tillandsia, Vriesia, and Guzmania and described different stages of development in two unidentified species of Tillandsia and Vriesia. His results are similar to those found in this study, with a few exceptions. Whereas the juvenile leaves in $T$. deppeana usually reach lengths of 5 to $6 \mathrm{~cm}$, the juvenile leaves of the Tillandsia

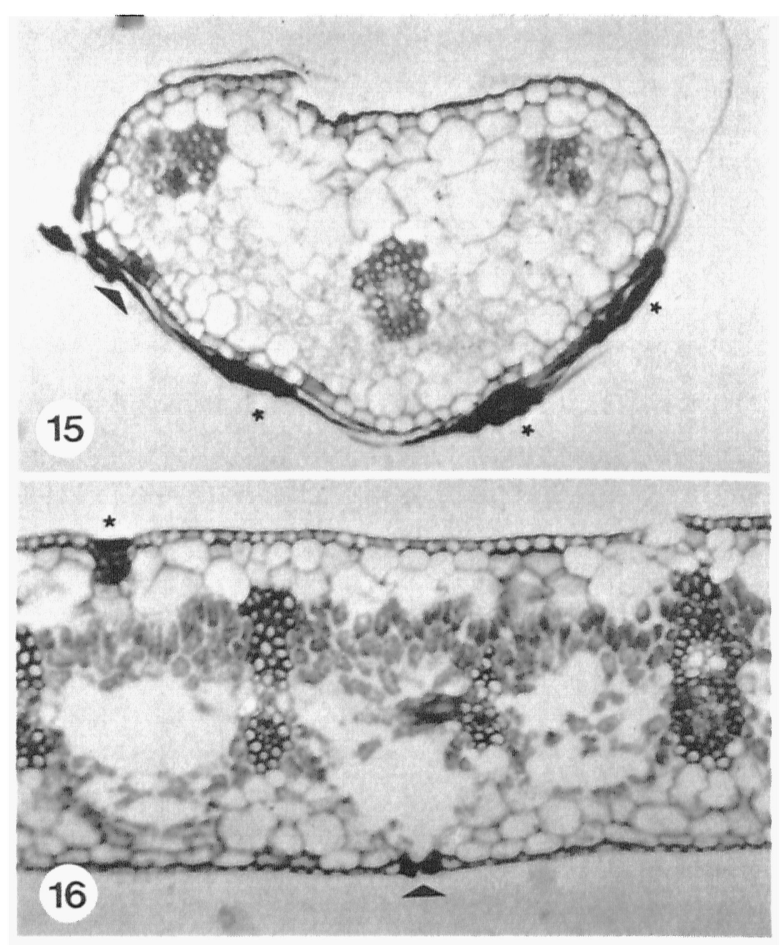

Fig. 15-16. Light micrographs of cross sections of Tillandsia deppeana leaves. Arrows indicate stomata, stars indicate trichomes. 15. Distal portion of juvenile leaf. $\times 125$. 16. Distal portion of adult leaf. $\times 125$.

examined by Lieske attain a length of $20 \mathrm{~cm}$ before broader leaves appear. He also reported that the density of trichomes in the juvenile leaves decreases toward the distal portion, while our study shows that the density of trichomes in the juvenile leaves of $T$. deppeana is uniform. The transition in overall leaf form appears to be as gradual as that found in $T$. deppeana, but he did not indicate whether there is also a persistence of juvenile trichomes in transitional leaves or whether there is any difference between juvenile and adult trichome structure.

Of the atmospheric tillandsias examined thus far, the most common pattern of cells in the trichome shield appears to be $4+8+16+$ 64 (Tomlinson, 1969; Gardner, 1982). On the other hand, $4+8+32$ appears to be the most common cell sequence in the trichome shields of tank-forming tillandsioids. This has been observed in two species, $T$. complanata and $T$. fendleri (Tomlinson, 1969), which are similar to the adult individuals of $T$. deppeana. Tillandsia fendleri also undergoes a transition from an atmospheric juvenile to a tank-forming adult (Medina, 1974), but whether trichomes of the juvenile leaves possess the $4+$ $8+16+64$ cell pattern is not indicated. Gardner (1982) observed a cell pattern of $4+$ 
$8+32$ in the trichome shields of the adults of three tank-forming tillandsias $-T$. multicaulis, $T$. imperialis, and $T$. deppeana. In addition, the trichomes on juvenile T. multicaulis leaves, which are linear and non-impounding as in $T$. deppeana, have the $4+8+16+64$ cell pattern characteristic of atmospheric epiphytes (Gardner, 1982).

The juvenile-to-adult shift in trichome structure found in $T$. deppeana and $T$. multicaulis is correlated with changes in leaf morphology and considerably alters the mode of water and nutrient acquisition. In the juveniles the overlapping, elaborate trichome wings enhance the dispersion of water (and nutrients) over the entire foliar surface (Benzing, 1976) whereupon it is absorbed by the trichome stalks. Trichomes with such elaborate wings are absent in the adult plants. Water and debris are impounded in the leaf bases where water and nutrient absorption occurs (Benzing, 1970, 1980; Benzing et al., 1976). If atmospheric trichomes were present in the adult plants, not only would they tend to interfere with the funneling of water into the plants during periods of precipitation, but they would also undoubtedly promote the vertical movement and evaporation of water out of the leaf bases.

The uniform distribution of trichomes in the atmospheric juveniles ensures that foliar absorption occurs over all parts of the plant during precipitation (and possibly high humidity). The asymmetrical distribution of trichomes found in the tank-forming adults reflects the restriction of water and nutrient absorption to the sheathing leaf bases where water and debris are impounded. This distribution of trichomes has also been observed in other tank-forming tillandsioid species (Rauh, 1979; Benzing, 1980; but see Benzing and Renfrow, 1971). The greater density of trichomes found on the adaxial surface of the basal leaf portions of $T$. deppeana adults relative to the abaxial surface is also common in other tank-forming tillandsioid species (Benzing and Renfrow, 1971; Benzing, Seemann and Renfrow, 1978; Rauh, 1979).

Differences in trichome shield structure have been used as characters to aid in the delimitation of various tillandsioid taxa (Tomlinson, 1969; Gardner, 1982). Given the structural differences between juvenile and adult trichome shields of $T$. deppeana and $T$. multicaulis, as well as the variability found on the same leaf, caution should be exercised in the use of such characters in taxonomic studies.

The restriction of stomata to the abaxial leaf surface in $T$. deppeana is the common condition in most tillandsioids. Stomatal densities observed in both forms of $T$. deppeana are low compared to most terrestrial species and are comparable to those reported for succulents (Larcher, 1980; Bierhuizen, Bierhuizen and Martakis, 1984). As in T. deppeana, stomata in members of the Bromeliaceae are normally restricted to longitudinal series underlying longitudinal rows of mesophyll tissue. Such an arrangement should minimize the path of $\mathrm{CO}_{2}$ diffusion from the atmosphere to the chloroplasts. The lack of chlorenchyma, lack of stomata, and high trichome density found in the adult leaf bases contrasting with the presence of chlorenchyma, high stomatal density, and low trichome density toward the adult leaf apex are indicative of a shift in primary function from water and nutrient absorption at the base of the leaf to $\mathrm{CO}_{2}$ assimilation at the tip. Thus, whereas these functions are spatially separated in the adult leaf, all portions of the juvenile leaf are involved in water absorption and mineral procurement as well as carbon fixation.

Mez (1904) suggested that the atmospheric habit of the juveniles of tank-forming tillandsioids is a consequence of their inability to hold a sufficient reservoir of water. The development of impounding transitional leaves with atmospheric trichomes prior to the initiation of true adult leaves in T. deppeana would seem to lend support to this suggestion. Once having achieved a size sufficient to hold water the plants can more efficiently utilize carbon by reducing the investment in trichomes and hypodermis. This is supported further by the fact that offshoots developing from $T$. deppeana adults possess only adult leaves and can obtain water from the adult plant until an impounding rosette of sufficient size develops. Lieske (1914), however, states that offshoots in the tankforming tillandsioid which he studied are atmospheric. It is possible that he examined immature adults since offshoots which develop prior to the maturation of the adult rosette in some tank-forming tillandsias are atmospheric, whereas tank-forming offshoots arise after maturation (Rauh, 1979). Further investigation is necessary to determine the consequences of such different forms of offshoot development in these tank-forming tillandsioids.

Juvenile individuals of $T$. deppeana are found throughout the canopy, yet only a few individuals in the upper canopy are able to survive to become large tank-forming adults. This is probably not due to any physiological differences between the two, as such differences do not seem to indicate that the adult form would be unable to survive in the lower canopy (Adams and Martin, 1986a, b). The difference in juvenile and adult distribution may be accounted for, in large part, by the difference in 
their morphologies as well as the structure of the tree canopy. The atmospheric juveniles are able to acquire water and nutrients from rain and stemflow anywhere in the canopy. The tank-forming adults are dependent on the direct interception and impoundment of rain (or throughfall) and debris, since water and nutrients from rain and stemflow are less available. Deeper in the canopy there is less throughfall because of the screening vegetation above (Ford and Deans, 1978; Hutchinson and Roberts, 1981). In addition, the only sites which remain stable long enough for these epiphytes to mature (Benzing, 1981), or which are strong enough to support an adult tank and its impounded water, are the uppermost large oak limbs.

Juvenile and adult individuals of $T$. deppeana are clearly distinct morphologically, not only with regard to leaf form and rosette structure, but also in terms of trichome structure and density of trichomes and stomata. To what extent this heterophyllous condition is present in other tank-forming tillandsioids deserves further attention. Differences in the physiological response of each form of $T$. deppeana to changes in several environmental parameters emphasize the importance of the atmospheric juvenile in the establishment of this species in the epiphytic habitat (Adams and Martin, 1986a, b).

\section{LITERATURE CITED}

Adams, W. W., III And C. E. Martin. 1986a. Heterophylly and its relevance to evolution within the Tillandsioideae. Selbyana. (In press).

$\longrightarrow$ AND - 1986b. Physiological consequences of changes in life form of the Mexican epiphyte Tillandsia deppeana (Bromeliaceae). Oecologia, Berlin. (In press).

Benzing, D. H. 1970. Foliar permeability and the absorption of minerals and organic nitrogen by certain tank bromeliads. Bot. Gaz. 131: 23-31.

- 1973. The monocotyledons: their evolution and comparative biology. I. Mineral nutrition and related phenomena in Bromeliaceae and Orchidaceae. Quart. Rev. Biol. 48: 277-290.

- 1976. Bromeliad trichomes: structure, function, and ecological significance. Selbyana 1: 330-348.

. 1980. The biology of the bromeliads. Mad River Press, Eureka, CA.

-1981. The population dynamics of Tillandsia circinnata (Bromeliaceae): cypress crown colonies in southern Florida. Selbyana 5: 256-263.

- AND K. M. BURT. 1970. Foliar permeability among twenty species of the Bromeliaceae. Bull. Torrey Bot. Club 97: 269-279.

$\longrightarrow$, K. Henderson, B. Kessel, and J. Sulak. 1976. The absorptive capacities of bromeliad trichomes. Amer. J. Bot. 63: 1009-1014.
- AND A. RENFrow. 1971. The significance of photosynthetic efficiency to habitat preference and phylogeny among tillandsioid bromeliads. Bot. Gaz. 132: 19-30.

- J. Seemann, And A. Renfrow. 1978. The foliar epidermis in Tillandsioideae (Bromeliaceae) and its role in habitat selection. Amer. J. Bot. 65: 359-365.

Bierhuizen, J. F., J. M. Bierhuizen, AND G. F. P. MarTAKIS. 1984. The effect of light and $\mathrm{CO}_{2}$ on photosynthesis of various pot plants. Gartenbauwissenschaft 49: 251-257.

Ford, E. D., AND J. D. DEANS. 1978. The effects of canopy structure on stemflow, throughfall, and interception loss in a young Sitka spruce plantation. J. Appl. Ecol. 15: $905-917$.

GARDNER, C. S. 1982. A systematic study of Tillandsia subgenus Tillandsia. Ph.D. dissertation. Texas A\&M Univ., College Station, TX.

Hoagland, D. R., And D. I. ARnon. 1938. The waterculture method for growing plants without soil. Calif. Agric. Exp. Sta. Circ. 347.

Hutchinson, I., AND M. C. Roberts. 1981. Vertical variation in stemflow generation. J. Appl. Ecol. 18: 521-527.

LARChER, W. 1980. Physiological plant ecology. 2nd ed. Springer-Verlag, Berlin.

LIESKE, R. 1914. Die Heterophyllie epiphytischer, rosettenbildender Bromeliaceen. Jb. wiss. Bot. 53: 502510.

Matos, J., And C. Rudolph. 1984. Aspects of the life history of Tillandsia deppeana. In S. Gardner [ed.], Proc. 1982 world bromeliad conference, pp. 71-75. Mission Press, Corpus Christi, TX.

MCWilliams, E. L. 1974. Evolutionary ecology. In L. B. Smith, and R. J. Downs. Bromeliaceae. Part 1. Pitcairnioideae. Flora Neotropica Monogr. 14: 4045. Hafner Press, N.Y.

Medina, E. 1974. Dark $\mathrm{CO}_{2}$ fixation, habitat preference and evolution within the Bromeliaceae. Evolution 28: 677-686.

Mez, C. 1904. Physiologische Bromeliaceen-Studien 1. Die Wasserökonomie der extrem atmosphärischen Tillandsien. Jb. wiss. Bot. 40: 157-229.

Morren, É. 1873. Exposition de Liége. Belgique Horticole Annales D'Horticulture Belge et Etrangere 23: 137-138.

Padilla, V. 1973. Bromeliads. Crown Publishers, N.Y.

Pittendrigh, C. S. 1948. The bromeliad-Anophelesmalaria complex in Trinidad. 1-The bromeliad flora. Evolution 2: 58-89.

RAUH, W. 1979. Bromeliads for home, garden and greenhouse. Blanford Press, Poole, England.

Schulz, E. 1930. Beiträge zur physiologischen und phylogenetischen Anatomie der vegetativen Organe der Bromeliaceen. Bot. Arch. 29: 122-209.

Smith, L. B., AND R. J. Downs. 1977. Bromeliaceae. Part 2. Tillandsioideae. Flora Neotropica Monogr. No. 14. Hafner Press, N.Y.

SOKal, R. R., AND F. J. Rohlf. 1981. Biometry. 2nd ed. W. H. Freeman and Co., San Francisco.

Tomlinson, P. B. 1969. Anatomy of the monocotyledons. III. Commelinales-Zingiberales. Clarendon Press, Oxford. - 1970. Monocotyledons-morphology and anatomy. Adv. Bot. Res. 3: 207-292. 